\title{
Economic perspective of dementia care in Pakistan
}

Ali Thaver, MD, MSc, and Arsalan Ahmad, MD

Neurology ${ }^{\circledR}$ 2018;90:e993-e994. doi:10.1212/WNL.0000000000005108

\section{Correspondence}

Dr. Ahmad

arsalanahmad65@gmail.

com

Dementia has a range of outcomes that includes declining memory, multiple cognitive deficits, and mortality due to brain damage. Developing countries bear the burden of $60 \%$ of patients with dementia worldwide. ${ }^{1}$ Pakistan is the sixth most populated country and has an estimated 150,000-200,000 patients with dementia. In light of improving health indicators, average life expectancy has increased. With an increase in the elderly population, the prevalence of dementia is expected to rise. Among people older than 65 years, the prevalence of dementia is expected to increase from $2 \%$ to $6 \%$ over the next 30 years. ${ }^{2}$ This poses an economic challenge for the population that bears $67 \%$ of the cost of health care through out-of-pocket payments. ${ }^{3}$ Traditionally most health care is consumed by the population in the latter age spectrum; therefore people in Pakistan who retire at the age of 60 rely on the government pension scheme and their savings for health care costs.

Shifa International Hospital in Islamabad, Pakistan, has a dementia registry and has published national dementia guidelines that in addition to pharmacologic treatments also focus on behavioral issues and caregiver concerns. ${ }^{2}$ Management is focused on improving functional capability and quality of life and helping patients remain as independent as possible to be the authors of the last chapters of their lives. In the absence of a geriatric medicine subspecialty in Pakistan, dementia care falls under neurology and psychiatry's domain. Elder care is usually assumed by family members and the concept of transitioning loved ones into nursing homes is not common. This works well for patients who live in familiar surroundings with people who know them best; however, there is a high opportunity cost (in terms of time lost) for economically productive individuals who take care of these patients or direct costs if they have to pay for their care. With a per capita income of $\$ 1,500$ and high reliance on out-of-pocket payments, not everyone can afford such ventures.

There has been work towards developing a national health insurance scheme in Pakistan, which is expected to decrease out-of-pocket costs. Though an important step to help save money, it will not directly deal with dementia at present. Expanding the pension scheme (\$50 per month) would require increasing the national budget or increasing the retirement age to 65 to boost economic productivity. However, these suggestions are based on the assumption that people would be able to save money, have adequate knowledge about their current and future health concerns, and use it when needed. This uncertainty will not translate into political action.

In Pakistan, many traditional birth attendants have been trained to deliver babies in the absence of obstetricians. This has been shown to improve maternal and child outcomes. ${ }^{4}$ Similarly, many housemaids take care of elders, including dementia patients, and can be categorized as informal caregivers. Formally training these housemaids for dementia care can improve patient outcomes. The project can be set up by using courses certified by the US Alzheimer's Association for home care givers including their program on Changing Aging Through Research and Education. These resources can be translated in regional languages in the cultural context of the country. Nurses experienced in geriatrics can run training workshops. The target population would be housemaids who either take care of the elderly as part of their job or those who intend to. Housemaids already aid in most independent activities of daily living. The training will focus

From the Department of Hospital Medicine (A.T.), University of Chicago Medical Center, IL; and Department of Neurology (A.A.), Shifa International Hospital, Islamabad, Pakistan. Go to Neurology.org/N for full disclosures. Funding information and disclosures deemed relevant by the authors, if any, are provided at the end of the article. 
on how to facilitate activities of daily living for patients with dementia, pill box management, identifying pressure ulcers, and contacting higher level providers in selected situations. Outcomes will be measured as decrease in rate of hospitalizations, decrease in falls, improved medication adherence, and family satisfaction rates pretraining and post-training. A pilot project can be run in a district in Pakistan to elucidate outcomes of training. Dissemination of project findings at the federal level will help gain government support to adopt it at the national level.

By setting up this program, we estimate at least $\$ 100$ million in savings to society over 10 years. Data from India with a similar social setup was used from the 10/66 Dementia Survey to provide close approximations of dementia costs in US dollars. India had an estimated 3.7 million patients with dementia in 2010 with a societal cost of $\$ 3.4$ billion/year. Pakistan has 0.2 million patients, which would calculate to a cost of $\$ 200$ million/year ( $\$ 3,400$ million $\times 0.2 / 3.7)$. According to the study, $60 \%$ of costs are indirect, which in Pakistan would be $\$ 120$ million ( $\$ 200$ million $\times 0.6$ ). Direct costs including hospital bills and medication copays would be $\$ 80$ million. An average of $\$ 12 /$ month for trained housemaids is $\$ 120$ /year for one individual and \$24 million $(240 \times 0.2$ million patients) for all patients. Assuming $50 \%$ of direct costs can be offset by trained caregivers, $\$ 40$ million of hospital costs (50\% of $\$ 80$ million) can be prevented, with a net saving of \$16 million ( $\$ 40-\$ 24$ million) every year.

This calculation did not take into account nonhousemaid care, changing costs of trained caregivers, and cost of developing a country-wide infrastructure. However, a higher average of housemaid pay was used compared to the 10/66 Dementia study. Even if $\$ 6$ million is spent every year on infrastructure and teaching, $\$ 10$ million dollars remain. This would surmount to net savings of $\$ 100$ million over 10 years keeping all other factors constant.

Another area of interest is the unmet demand in Pakistan to create affordable retirement homes. Due to a greater participation of women in the workforce, there is a growing need for support to help with elderly care. However, there is no public sector interest in this area. Alzheimer's Pakistan, a nongovernmental organization in collaboration with Alzheimer's Australia, has set up a day care center in Lahore, Pakistan. There are also some well-structured old homes that have been established in the southern part of the country run by minority communities. Apart from these, only a few unregulated informal care facilities exist that cater to the elderly.

To promote health care service delivery, private equity firms have expressed a desire in investing in innovative models for elder care in neighboring countries China and India. With strong private buying power in Pakistan and an inclination to use private services for dementia care, affordable elder care homes may be a viable business option. ${ }^{5}$ Decreasing barriers to market entry and promoting local entrepreneurs in health care will stimulate both local and foreign investments. At present, the country is far from having privately run government-owned elder care facilities like the United Kingdom, but political momentum can help the country head in that direction. We hope our ideas will help initiate discussions to formulate a dementia-specific federal health policy.

\section{Author contributions}

Ali Thaver: conceptual framework, literature search, writing. Arsalan Ahmad: design, writing disclosures.

\section{Study funding}

No targeted funding reported.

\section{Disclosure}

The authors report no disclosures relevant to the manuscript. Go to Neurology.org/N for full disclosures.

\section{References}

1. Rizzi L, Rosset I, Roriz-Cruz M. Global epidemiology of dementia: Alzheimer's and vascular types. Biomed Res Int 2014;2014:1-7.

2. Ahmed A, Owais K, Siddiqui M, Mamun K, Rao F, Yousufzai A. Dementia in Pakistan: national guidelines for clinicians. Pakistan J Neurol Sci 2013;8:17-27.

3. Malik AM, Syed S. Socio-economic determinants of household out-of-pocket payments on healthcare in Pakistan. Int J Equity Health 2012;11:51.

4. Islam A, Malik F. Role of traditional birth attendants in improving reproductive health: lessons from the family health project, Sindh. J Pak Med Assoc 2001;51: 218-222.

5. Prince M. Care arrangements for people with dementia in developing countries. Int J Geriatr Psychiatry 2004;19:170-177. 


\title{
Neurology
}

\author{
Economic perspective of dementia care in Pakistan \\ Ali Thaver and Arsalan Ahmad \\ Neurology 2018;90;e993-e994 \\ DOI 10.1212/WNL.0000000000005108
}

This information is current as of March 12, 2018

\section{Updated Information \& Services}

\section{References}

Citations

Subspecialty Collections

Permissions \& Licensing

Reprints including high resolution figures, can be found at: http://n.neurology.org/content/90/11/e993.full

This article cites 5 articles, 0 of which you can access for free at: http://n.neurology.org/content/90/11/e993.full\#ref-list-1

This article has been cited by 1 HighWire-hosted articles: http://n.neurology.org/content/90/11/e993.full\#\#otherarticles

This article, along with others on similar topics, appears in the following collection(s):

All Cognitive Disorders/Dementia

http://n.neurology.org/cgi/collection/all_cognitive_disorders_dementia Cost effectiveness/economic

http://n.neurology.org/cgi/collection/cost_effectiveness_economic_ Quality of life

http://n.neurology.org/cgi/collection/quality_of_life

Information about reproducing this article in parts (figures,tables) or in its entirety can be found online at:

http://www.neurology.org/about/about_the_journal\#permissions

Information about ordering reprints can be found online:

http://n.neurology.org/subscribers/advertise

Neurology ${ }^{\circledR}$ is the official journal of the American Academy of Neurology. Published continuously since 1951, it is now a weekly with 48 issues per year. Copyright (O 2018 American Academy of Neurology. All rights reserved. Print ISSN: 0028-3878. Online ISSN: 1526-632X.

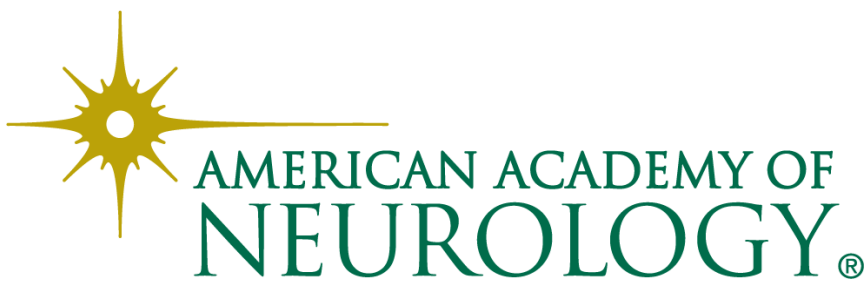

